\title{
67- Local ecosystems, biodiversity and sustainability: bioregional reading of Mary Hunter Austin's The Land of Journey's Ending
}

Barış AĞIR'

APA: Ağır, B. (2021). Local ecosystems, biodiversity and sustainability: bioregional reading of Mary Hunter Austin's The Land of Journey's Ending. RumeliDE Dil ve Edebiyat Araştırmaları Dergisi, (25), 1089-1102. DOI: 10.2900o/rumelide.1037123.

\begin{abstract}
American writer Mary Hunter Austin's passion for living a bioregional lifestyle is conveyed in her works, which may be applied on a larger scale to help build a stronger civilization that is environmentally minded and emphasizes the mindset of bioregions in terms of self-sufficiency rather than global homogenizing interconnectedness. This study examines Austin's literary non-fiction, The Land of Journeys' Ending, from a bioregional lens, as it focuses on the American Southwest and its indigenous inhabitants, who live harmoniously with the land. Austin's passion for Native American culture was profound as were her convictions about their lifestyle, including their spiritual life and cultural heritage, which were adapted to suit the local landscape and its natural conditions/features that they highly valued. The emphasis on preserving local culture, politics, and economies of Austin's work could contribute to deepening the understanding of bioregionalism's potential influence in a modern context, especially as a response to the global monoculture crisis. Thus, the paper delves into Austin's notable work in an effort to reveal her position about how humans should construct a beneficial relationship with the natural world based on a local context.
\end{abstract}

Keywords: Locality, bioregionalism, biodiversity, culture, sustainability

\section{Yerel ekosistemler, biyoçeşitlilik ve sürdürülebilirlik: Mary Hunter Austin’in The Land of Journey's Ending eserinin biyobölgeselci okuması}

$\ddot{0} \mathbf{z}$

\begin{abstract}
Amerikalı yazar Mary Hunter Austin’in biyobölgeselci yaşam sürdürme tutkusu eserlerinde sıklıkla görülen bir olgudur. Bu durum, çevre bilincine sahip daha güçlü bir uygarlık inşa etmeye yardımcı olmak için daha büyük ölçekte uygulanabilir ve küresel homojenleştirici ilişki yerine kendi kendine yeterlilik açısından biyobölgelerin düşünce yapısını vurgular. Bu çalışma Austin’in, Amerika'nın güneybatısında ve toprak ile uyumlu bir şekilde yaşayan yerli halkları anlattığı The Land of Journey's Ending eserini biyogölgeselci bir bakıç açısıyla incelemektedir. Austin’in kızılderili kültürüne olan derin tutkusu, kızılderililerin oldukça kıymet gösterdikleri yerel tabiata ve doğal koşullarına/özelliklerine uyumlu manevi yaşamları ve kültürel mirasları ile ilgilidir. Austin’in bu eserinde yerel kültürü, siyaseti ve ekonomileri korumaya yaptığı vurgu, özellikle küresel monokültür krizine bir yanıt olarak, modern bağlamda biyogölgeselciliğin potansiyel etkisi hakkındaki anlayışın derinleşmesine katkıda bulunabilir. Bu nedenle, bu çalışma Austin’in eserinin, insanların yerel bir bağlama dayalı olarak doğal dünya ile nasıl faydalı bir ilişki kurması gerektiği konusundaki konumunu ortaya çıkarmayı amaçlamaktadır.
\end{abstract}

Dr. Öğr. Üyesi, Osmaniye Korkut Ata Üniversitesi, Fen Edebiyat Fakültesi, İngiliz Dili ve Edebiyatı Bölümü (Osmaniye, Türkiye), barisagir@hotmail.com, ORCID ID: oooo-0002-7132-5844 [Araştırma makalesi, Makale kaylt tarihi: 01.11.2021-kabul tarihi: 20.12.2021; DOI: 10.29000/rumelide.1037123] 
Anahtar kelimeler : Yerellik, biyobölgeselcilik, biyoçeşitlilik, kültür, sürdürülebilirlik

\section{Introduction}

American writer Mary Hunter Austin became an early advocate for environmental issues, the preservation of Native American culture, and women's rights as well as those of other minority groups. Although Austin was a well-known, respected author and activist during her lifetime, she receives scant recognition today-like other female writers of her period-for her original style of prose and social critiques, even though her voice is one of the most unusual, gifted, eccentric, and tragic in American literature. Austin "earned her reputation as the most famous female nature writer of the period" (Norwood, 1993, p. 49); specifically, her remarkable nature writing clarified the direction she was moving in as an artist, feminist, environmentalist, and mystic.

The Land of Journeys' Ending was first published in 1924 and it provided "the writer with an opportunity to return to the literary form that had launched her career, the descriptive prose that came naturally to her in The Land of Little Rain and The Flock" (Stineman, 1987, p. 367-368). It marked a temporary departure from the social and political concerns she had dealt with and the philosophical questions she had tried to answer in Love and the Soul Maker, a cultural analysis that undergirded The American Rhythm, and the reformist issues she had addressed in her journalism. The Land of Journeys' Ending also recovered an authentic heritage from the Native Americans, many of whom were elderly, including folklore and beliefs that Austin encountered. "With its focus on New Mexico landscape and culture"(Champion, 2000, p. 13), New Mexico was the perfect location for Austin to elaborate on ideas of the deep self which she had held onto for years.

The Land of Journeys' Ending is a memorable, stimulating work in which Austin expresses the value of Native Americans. As Klimasmith states, "Austin describes a variety of famous and lesser-known places and regional practises in Journey's Ending, utilizing her broad, evocative style to construct a mystical sense of place as a confluence of history, geography and human activity" (2004, p. 57). By demonstrating the significance that Austin attaches to bioregions in her writing, this paper reveals her position: To construct a harmonious relationship between humans and nature, she inspires her readers to feel concerned for the natural world. She posits that we should take measures based on the local conditions. Within this sense, this is a bioregional study of Austin's literary non-fiction, The Land of Journeys' Ending, aiming to enrich the research behind Austin's works and provide hints in terms of the construction of an ecological civilization.

Bioregionalism was first conceived of by the radical activist, Allen Van Newkirk and later adopted by "Peter Berg and Raymond Dasmann in the 1970s" (Peterson, 2018, p. 667). Lawrence Buell defines the term as follows:

Bioregionalism is a philosophy or vision, originating in the American west during the 1970s, of life in place conducted in so far as possible in deference to the ecological limits of the place where one lives. From the perspective of ecology, a bioregion or ecoregion is a geographical area of similar climate where similar ecosystems and groups of species are found on similar sites. Bioregionalism, however, views a bioregion not only as a territory defined by natural markers, such as watersheds, but also as a domain of consciousness and as a focus of citizenly allegiance that challenges conventional political boundaries. Bioregionalism aspires to respect and restore natural systems while satisfying basic human needs in sustainable ways, believing that geographical units of relatively small scale are likeliest to promote such engagement. (2005, p.135) 
Meanwhile, bioregionalism provides the necessary context for achieving sustainable, decentralized, and regenerative communities. Kirkpatrick Sale concerns how bioregionalism teaches one how to become a dweller of the land and summarizes the concept of bioregionalism:

\begin{abstract}
But to become dwellers in the land, to relearn the laws of Gaea, to come to know the earth fully and honestly, the crucial and perhaps only and all-encompassing task is to understand place, the immediate specific place where we live. The kind of soils and rocks under our feet; the source of the waters we drink; the meaning of different kinds of wind; the common insects, birds, mammals, plants and trees; the particular cycles of the seasons; the times to plant and harvest and forge--these are the things that are necessary to know. The limits of its resources, the carrying capacities of its lands and waters; the places it must not be stressed; the places where its bounties can best be developed; the treasure it holds and the treasures it withholds - these are the things that must be understood. And the cultures of the people, of the populations native to the land and of those who have grown up with it, the human social and economic arrangements shaped by and adapted to the geomorphic ones, in both urban and rural settings--these are the things that must be appreciated. That, in essence, is bioregionalism. (1985, p. 42)
\end{abstract}

Thus, bioregionalism represents the call to become knowledgeable guardians of the place one lives, whereas bioregionalists are primarily concerned with their local areas. Moreover, bioregionalists encourage people to understand their local land, water, weather, plants, animals, neighbors, and communities. Bioregionalists posit that people are also an integral part of the bioregions, as they affect them as much as they are impacted by them. The life of a bioregion ultimately supports human life, just as the way people live is becoming crucial in regard to the bioregion's ability to continue doing so. According to Robert L. Thayer Jr.,

A bioregion is literally and etymologically a "life-place"-a unique region definable by natural (rather than political) boundaries with a geographic, climatic, hydrological, and ecological character capable of supporting unique human communities. Bioregions can be variously defined by the geography of watersheds, similar plant and animal ecosystems, and related, identifiable landforms (e.g., particular mountain ranges, prairies, or coastal zones) and by the unique human cultures that grow from natural limits and potentials of the region. Most importantly, the bioregion is emerging as the most logical locus and scale for a sustainable, regenerative community to take root and to take place. $(2003$, p. 3 )

Deepening the concept of bioregionalism, Thayer argues that "the bioregional approach suggests a means of living by deep understanding of, and respect for, and, ultimately, care of a naturally bounded region or territory" (p. 124). Thus, bioregionalism offers an innovative way of thinking about a sense of place (and the planet) from an ecological perspective. It also offers a new territory for exploring literary criticism and provides a broad platform for studying Austin's The Land of Journeys 'Ending since it "focuses on the central "working relationship" between the land and its inhabitants" (Warren, 2014, p. 12). Embodying numerous concepts that align with bioregionalism, The Land of Journeys' Ending may be referred to as typical bioregional literary non-fiction.

\title{
American southwest and the natural world
}

Esther F. Lanigan states that "place was important to Austin, in both its environmental and its georgraphical and geopolitical aspects" (1989, p. 3). Austin aims to inspire others to preserve the original features of nature in the American Southwest. Throughout the book's journey, she praises the local, diverse trees and animals as well as the typical mountains and rivers in that region, especially in the areas occupied by Native American clans in the Pueblo and Papago country. From Austin's perspective, the natural beings that the indigenous people of the Pueblo and Zuni clans pay special attention to and use daily hold significant value. The concept of bioregionalism seeks to protect (rather than exploit) the natural world, which is expressed by the Native Americans, who rarely exploit the natural world and 
even take the initiative to protect the abundant plants and animals, which they view as divine creatures, as well as the holy mountains and sacred rivers; in return, these natural beings provide the local people with food and a harmonious environment that is not in danger of being polluted. In The Land of Journeys' Ending, natural elements are depicted from the perspective of these natural beings. Austin posits that the plants have value and merit; every plant has individual use for the indigenous people. Cedar boughs, for instance, make the best bows, the powdered bark of mulberry makes excellent tinder, and the Papagos utilize bunchgrass and bear-grass for their basketry practices. Additionally, native plants have special meaning to the local people. In the northern Pueblos, aspen represents the golden east, where their hero, Poseyemo, is expected to return from, and at a festival, dancers hold aspen boughs toward the rays of departing Poseyemo to memorize him.

Being subject to the same arid conditions as humans, plants can only survive by adapting to the local, harsh environment. Thus, they have a strong ability to adapt to these arid environments of the Southwest country that have a limited water supply, and different plants have evolved a variety of growth habits. Local plant growth will occur at a plant's specific preferred latitude, according to the rhythms of the land. For instance, "cottonwood, alder, chokecherry, mulberry, and aspen" (p. 41) grow at the bottom of deep canyons, while dwarfish oaks can be found in steep cumbres. In the lower country below the Rim, two general types of adjustment occurs. First, the vegetating stage of plants speeds up, while it takes the entire summer for flowers and fruit that are growing elsewhere to achieve the same results. The second type of adjustment is that the life of an individual plant becomes infinitely prolonged (p. 49). Austin eulogizes plants as follows: "Not one of all the ways by which a tree strikes freshly on your observation,--with a greener flush, with stiffened needles, or slight alterations of the axis of the growing shoots, accounts for this flash of mutual awareness" (p. 176).

While describing the Southwest in The Land of Journeys' Ending, Austin shows a special interest in the cactus and describes several types of cactus in the chapter, "Cactus Country." The cactus is a typical plant with a strong vitality, and because of its adaptations to extreme conditions, it grows densely in this arid region. One of the cactus types mentioned is the sahuaro, which grows to be twenty-five or even thirty feet high. The sahuaro is valuable to the indigenous people in many ways, as its pocket linings can make household containers, for instance, and the Papago utilizes them for the roofs of their houses and even their family tombs. Furthermore, the sahuaro's wine and luscious, juicy pulp are some of the oldest beverages in the region. The virtues of the ocotillo and barrel-cactus should also be mentioned, as the stem of the ocotillo is utilized for constructing chicken fences and corrals, while the maceration of the barrel-cactus' white pulp provides a slightly insipid drink. When considering the copious contributions that a cactus provides to the local Native Americans, the people of Pagagueria began to realize the necessity of protecting this precious plant. Thus, "it is a crime to destroy a sahuaro" (p. 125) in Pagagueria, which protects the cactus well, allowing it to rapidly flourish.

Overall, the plants benefit local Native Americans significantly. While the cactus provides the Papago people with delicious food, the guayule has medical value. Austin writes, "Guayule, moving to make rubber as plentiful as it is indispensable to our culture, sotol with its fiber, osha with its healing, the light, springy wood of the sahuaro and the Joshua-tree, hohoba, sangre de drago, the enduring dye and incomparable honey pasture of the Rocky Mountain bee-weed" (p. 283). In general, the local plants are considered to be gifts from God. Therefore, instead of cutting down these trees, the aboriginal people make every effort to preserve and care for the plants to maintain a sustainable environment. 
Austin also cares for the local animals and values their lives, advocating for others to do the same. On a mountain along the Lost Borders, she would occasionally catch a rabbit: "I turned quickly and went another way; not for worlds would I have scared it from the mountain" (p. 388). During the next season, she returned there with an acquaintance and writes, "in my excitement to discover that the rabbit had found a mate, I cried out" (p. 388). However, her acquaintance "was of the sort in whom a mountain wakes only the love of killing" (p. 388), so he killed the rabbit, which made her incredibly sad.

Austin provides a detailed description of animal ecosystems from the perspective of the Pueblo peoples, and she explains how animals are beneficial for forming a sustainable environment in the arid Southwest. In her eyes, a rooted inhabitant should have excellent knowledge of the local animals: "The man in that country who cannot tell you a good pack-rat story is no native, but a tenderfoot. For no man has ever really entered into the heart of any country until he has entered the heart of any country until he has adopted or made up myths about its unfamiliar objects" (p. 302). Austin explains how the animals are perceived by the indigenous clans as creatures that are nearer to the gods than humankind. For example, the local people would make confessions through a series of prayers while killing the native animals for their food. Thus, we can conclude that the native animals hold a high position in Native American clans.

Deeply touched by a raccoon family, Austin advocates for the protection of raccoons and forming a harmonious living environment between people and animals. In San Juan Pueblo, Austin observes several racoons:

\begin{abstract}
A whole family would come, parents and three little ones, and one or two others that I supposed might be the young of last year. Half an hour earlier, I heard them up the Canada, calling softly to the rendezvous, but when they arrived, how still they could be, and how merry! Chasing and tagging one another in the intervals in which their elders, reaching far into the hollowed rind, would scoop out a handful of juicy pulp for each in turn. Occasionally one would be bunted quite over. Then the soft whimpers and giggles, and the admonitory squeaks! In the morning nothing left but a rind scooped paper thin; not a seed nor a dropped morsel on the clean sand, patted over as with the prints of a child's slender hand. (p.288)
\end{abstract}

The pronghorn, "a frequenter of the dry-grass country" (p. 291), also impresses Austin with its gentleness and childlike curiosity. Though it is mostly a timid animal, the pronghorn would fight against the eagle and gray lobos to protect its young. Also, two species of deer in Kaiab left an unforgettable impression on Austin: the blacktail and whitetail. The ears of blacktail deer are so sensitive that they can differentiate slight alternations in forest sounds, and they have large appetites: "bands of blacktail can be found in the dark of the moon, feeding late into foggy mornings" (p. 292). Austin believed that they should be honored for their "steel-tendoned legs" (p. 293) because they are just as "sure-footed as a mountain sheep and wary as an antelope" (p. 293). In comparison, the whitetail deer are fewer in these arid regions and live in the ciénegas, brush-land, and forest country, tending to keep within the canebrake, as though the brush still hid them. Similar to the blacktail deer, "it goes by long spring bounds, three or four in clusters separated by one high and curved like the flight of a bird" (p. 294). Thus, the light-stepping whitetail deer is regarded as a sort of sportsman by the local people.

To some degree, the locals kill animals for food to avoid extreme hunger, but since this obliterates the harmony between nature and humans, they recognize this behavior as brutal and immoral. As a result, they make peace with their guilty conscience through prayers, while killing the animals: "O our brother of the wilderness, for our necessities we are about to kill you. We hope that you will understand, and that there may be peace between your spirit and our spirit" (p. 289). Native Americans consider the 
beast a brother and believe that animals possess a special superiority: "Animals more powerful than man, and all of them more mysterious, were thought of as being nearer to the gods than men. They were prayed to and propitiated as intercessors" (p. 304). Similarly, it is undeniable that Austin was also a nature lover, who cared for the local animals: "A furry, fairy shape, its foot-high banner glistening, Christmas white, utterly lovely and unfamiliar of its kind, which was scarcely noted until a glimpse of short, soot-black legs moving it about, and a sooty nose directing it, warned us to back softly, and hope it had business of its own from which it might not be easily distracted" (p. 301).

In her work, Austin delineates between a wide variety of mountains and rivers, which form favorable living atmospheres for the aboriginal peoples. The Rio Grande and The Rio Colorado provide them with irrigation and water, while the mountains in Navajo country bring them a sense of tranquility. These holy mountains and sacred rivers transform the arid Southwest into a vibrant, energetic landscape. Undeniably, the local mountains and rivers play important roles in the native people's lives. According to Austin, every mountain in Navajo country has a distinctive feature and personality. For example, "the bulk of Tsotsil, as blue as a summer rainstorm" (p. 375) is a "rim-rock mesa, red sandstone, topping the softer stuff and weathering in huge blocks like a ruined wall" (p. 376). Unlike the blue Tsotsil, the base of Sunset Crater is black; it is cup-shaped and overlaid across "its rim with red cinders, yellowing toward the top", (p. 377) creating a glowing effect, like fire, that is produced even during winter snows.

These mountains between the Rio Colorado and Rio Grande also share similarities. They evoke a sense of awe, as they change with the light and grow increasingly beautiful with the passage of time in the eyes of the aborigines. For example, young mountains are considered terrible and hard because nothing can grow on them yet, except lichen and seaweed. As these new mountains mature, they obtain a higher position among the locals, who view them as pure and holy, like gods, honoring them as "makers of men's minds" (p. 383). As such, they are endowed with emotional significance by the aborigines. There are shrines "on Lake Peak, the crest of Oku, sacred Tewa turtle, and the high peak of Jemez", (p. 384) which gives the people continual "shivers [of] Panic" (p. 384). Even today, one may feel a sense of discomfort when facing mountains' stark stone. There are also "dead" mountains in Navajo country, which do not have names. No one has even stepped inside the "blind cinder-heaps, cupped craters, wedged-shaped dikes surviving the cleft sandstone walls that shaped them” (p. 386). These mountains in Navajo country change with the changing light, like the peaks of Jemez, which are blue in the morning and evening light except during the twilight of spring when it shines with a green light (p. 389). Shaken by the beauty of these mountains, Austin eulogizes them:

\begin{abstract}
Not beauty only, for there is a special kind of beauty for every hour the mountain knows, beauty which man perceives without participating, beauty to which he feels himself a stranger. There is the beauty of the structureless gloom of gathering storms, beauty with terror of the milling maelstroms of the air, beauty edged with intolerable loneliness of the moon-bow flung on the fluffy, silver-flecked floor of cloud observed from peaks above the tree line. (p. 390)
\end{abstract}

Also, in The Land of Journeys' Ending, Austin depicts two important rivers that have significant meaning to the aborigines: the Rio Grande and Rio Colorado. Although they have different environments and take separate paths, they share some similar features. For example, they were both created by the special geographical factors of the arid Southwest and nourished the local people, animals, and plants. In addition, as a source of irrigation and water, these rivers also generated splendid civilizations that live alongside them. Thus, the Native Americans respect these rivers and even regard them as their holy mother. 
The Rio Grande is not only the fifth-longest river in North America but the twentieth longest river in the world, forming a natural border between the state of Texas and Mexico. Although a large proportion of the river's basin is arid or semiarid, the Rio Grande receives snow water and torrents of rain from the slope of Culebra, and the waters cross rich agricultural regions as it flows toward the Gulf of Mexico. Along the upper river (called Rio Arriba), where there are no tall trees, the Grande flows through countless mountains and plateaus. One can even "read the weather in the distant mountains by the color of the Grande" (p. 174).

Austin also provides a brief introduction to the history of the Rio Grande pueblos. For example, the latter district of Rio Grande (called Rio Abaja) begins at Bernalillo. Numerous plants, such as aspens and rabbit-brush, flourish along this great river. Rich as it is, the Rio Abaja is filled with fertile flood and full of bean-culture and corn-culture which is created by the native pueblo clans. Even the conquistadors assimilated by adjusting to this culture. Described as a "history maker" (p. 202), the Rio Grande is considered to have recorded the historical conflicts between the Spanish pioneers and the Pueblenos. Its clear streams, swift but not dangerous, also provide a suitable environment for the growth of local animals: "Where the gorge recedes, rounding the Horse-shoe turn, beaver make their home, and farblown water-fowl come up from the gulf to breed. Smoke-colored bighorn feed among the rainbow buttes" (p. 406).

In summary, the Native Americans do their utmost to protect and value the natural features that are local to them. Austin contends that these resources hold significant value for the local peoples, so they should be protected and cared for as a result. Similarly, she also values the local trees, animals, mountains, and rivers. Throughout her journey, she expresses the belief that the local people's sense of protection toward these local, natural beings should be praised.

\section{Culture and diversity}

Austin insists that the cultures based on bioregions (i.e., ones that adapted to the local conditions) should be preserved to attain cultural diversity. Furthermore, Austin eulogizes native people's commitment to preserving these bioregional cultures, including their mode of traditional agriculture, rites, ceremonies, vernacular language, and artistic traditions. As Heike Schaefer states, "to keep faith with the land in this sense, means to keep faith with our culturally and personally mediated experiences or embodied readings of the land" (2004, p. 37). The rich, colorful aboriginal cultures between the Rio Grande and the Rio Colorado also affect the cultural history of the American Southwest to some extent. The natives maintain cultural diversity and resist the dominant culture, which seeks to draw out as many people as possible to join an urban, upscale lifestyle, wiping out regional differences.

Austin proposes retaining traditional agriculture and explains that corn is one of the typical crops in Native American clans, regarded as a quickening agent for the local agriculture. In fact, the development of traditional agriculture in these clans began with the cultivation of corn, so it undoubtedly plays an important role in the development of local agriculture, especially during the Small-house period. Corn had been extensively planted since ancient times-regarded as the oldest cereal grain in the world by the native peoples-so it maintains an unshakable position as one of the main food staples among the native clans.

In the process of developing local traditional agriculture, Austin posits that corn has three significant merits. First, corn significantly contributed to local agriculture as the main food source for local clans 
across several generations. Austin explains, "so long ago it was, that there has been time for corn to fossilize along with the fossil remains of man, in the shape of the short, roundish, pointed grain, closepacked ears, as the oldest cereal in the world" (p. 281). During the Pit-house period, corn planters were referred to as "People of the Seed," and it is undeniable that corn significantly impacted Pueblo agricultural culture. Furthermore, "every now and then, the archaeologist uncovers a wall cache of shelled corn, forgotten as long ago as the time an English king tended cakes in a cowherd's hut" (p. 78). In this culture, even the seed of the corn could be used as a reserve against the potentiality of a cropless year as well as for the tithing of a cacique.

Second, the corn has also enriched the spiritual life of the Pueblo clan, who celebrated the harvest in unique ways. For example, the ancient Pueblos used to create the drama of the corn and the figure of Six Corn Maidens. According to Austin, "long before it came into our Southwest, the corn had established itself as the friend and the familiar of man" (p. 282). With the arrival of corn, there were also rites, ceremonies, and festivals, involving the periods of planting seeds and harvest.

Third, corn accelerated the transformation of architectural processes. To protect their corn from pests and temperature fluctuations, the people of Papagueria thickened the mud walls that surrounded the crop, for example. Farther north, where heavier snows and longer periods of cold weather had rendered the jacal impracticable, pit-houses were constructed with cobbles around the walls and plastered with clay. Continuing along the line of stones slightly above ground level, the pit-house builder laid his beams flatly across, evolving the style toward a bonded, cemented wall (p. 65).

Austin praises the Native American's preservation of their traditional agriculture, especially corn planting: "Whether or not the Small-house period began with corn, its economic and social and religious life revolved around it; for any people that live by corn becomes bond-servant of all its ways. Corn is a town builder, a maker of policies, mother of inventions. Out of its necessities were drawn architecture, philosophical systems, and the material of drama" (p. 72). Since the local environment is suitable for corn cultivation, Austin proposes that it has played an important role in developing local people's traditional agriculture as well.

In various places, local people have performed different rites and ceremonies, having a deep affection for their festivals that relate to their agricultural practices. Austin describes the Papago's sahuaro harvest and the Christian festivals during Holy Week in New Mexico. By observing festivals and rituals among the Pueblo, Austin concludes that rites and ceremonies should be appropriate according to the local, natural environment. Native Americans are keen to foster and enhance bioregional cultures, and this desire to maintain their rites and ceremonies is eulogized by Austin. Like The Land of Little Rain and (to some extent) Lost Borders, The Land of Journeys' Ending recovers an authentic folklore heritage, including bioregional rites/ceremonies and indigenous beliefs that Austin encountered during her arduous trip through Arizona and New Mexico.

Rites that invoke the flourishing of life exist among the pueblo clans in New Mexico. When the rite begins, there is dancing and the pueblos wear wreaths and armlets of Douglas spruce, a symbol of lifeeverlasting. In addition, young trees are brought down by the heads of the clan from distant ranges. At sunrise, the children are already pattering on the terraces in front of the festival (p. 44). In the northern pueblos, they practice the feast of Poseyemo, which is approximately the same day that celebrates a Christian saint, whose festival is also near the autumnal equinox (p. 45). At the feast, "dancers hold 
bright aspen boughs toward the rays of departing Poseyemo, the legend of whose journey south was very early assimilated to the sun-myth" (p. 45).

In another ritual, some pilgrims arrive on their knees as a sign of their enormous devotion and gratitude to Basilica of Guadalupe where the Lady Guadalupe is kept. People of all ages and from all regions of the country gather together both physically and spiritually, including numerous groups of dancers and musicians that come to offer their art to the Virgin. Although the Basilica of Guadalupe is where most of the rituals and celebrations take place on this special day, festivals erupt nationwide in honor of Mexico's Patron Saint.

In late June or early in July, a branch of the Papago begins to gather sahuaro as a response to the clan's new year. Ceremonial activity "begins with the ritualistic fermenting of the expressed juice of the first gathering" (p. 152). Then, the Papago sing and dance in the dark to celebrate the joyous occasion. They hold each other's "hands as they dance, and their ceremonial circle is against the sun" (p. 152). Afterward, the elderly men "sleep and sit at the ritualistic four quarters of the world under the direction of the Keeper of the Smoke" (p. 153). This activity aims to persuade the gods with song and admonish the people to "look for the shining house in the west where the black clouds are" (p. 153).

Besides celebrating the sahuaro harvest, the Papago also conduct a ceremonial race around the "salina" (p. 158) when they travel down to the sea to collect salt. They pray that the sea brings them many beneficial gifts: rain, health, and handsome wives. The neophytes are so devout that when they pray, they stand "knee-deep in the sacred sea" (p. 158), holding hands and "facing the morning" (p. 158). No matter how challenging it is, they endeavor to maintain their traditional rites and ceremonies because they believe that these practices will protect them from misfortune, bring them luck, and foster a bountiful harvest.

By staying in Santa Fe, New Mexico's capital, Austin can focus on describing the Christian rituals there, especially the Penitente crucifixions during Holy Week, which consist of whippings, fasting, gashing, and expiation via the maddening prick of a cactus thorn. All the Penitente crucifixions begin with Lent, which is a solemn observance in the liturgical year of many Christian denominations that lasts for approximately forty days leading up to Easter Sunday. The traditional purpose of Lent is the believer's preparation through prayer, penance, repentance, almsgiving, and self-denial. The Penitentes in New Mexico observe the funerals of their brothers on the first and second days of May to keep alive the memory of their Savior's suffering and death (p. 356).

The Christians have a strong penitential passion, which can be easily observed from the local whipping rites. Penitentes whip their bloodied backs during these rites to show their eternal reverence toward their Savior: "Intermittently in fives and threes ... First over one shoulder and then over the other" (p. 357). It seems that the harder they whip, the more reverent they believe they are. On Holy Thursdays, the Penitentes gather together and make their way to the "Calvario" (p. 356), which is located at a low hill, or to neighboring moradas. Under the leadership of the chosen "Cristo" (p. 361) of the year, the procession sings hymns and prays along the way. The hymns are sung with pain, as whips, wet with blood, fall steadily, "followed by that most desolating sound: the slither of the crosses in the dust" (p. 362). After all these whipping rites and activities, the weary brothers begin to prepare for the play, which has faithful, realistic detail. The local Christians put in extreme effort to restore the historical characters: "The Roman centurion with his spear, the Jewish constabulary, the three Marys with their lanterns, the 
sliders that died for the seamless robe" (p. 368). People in New Mexico have a strong spiritual frenzy toward Christian festivals and maintain a devout attitude when taking part in Holy Week's activities.

Austin becomes incredibly interested in these Christian festivals, straining her nerves to comprehend them and take part in the Penitente crucifixions. She depicts many of them in The Land of Journeys' Ending: the rites that invoke life, the feast of Poseyemo, the festival of Our Lady of Guadalupe, sahuaro harvest, and Christian rituals (e.g., Penitente crucifixions and Holy Thursdays). These rites and ceremonies are attentive to local conditions, and the people in the pueblo bioregion have a deep affection for their festivals, desiring to foster and enhance them.

In environmental writing, text and language are "so deeply connected to the specific dimensions of a particular landscape and climate that some of central claims may not be applicable to other parts of the world" (Garces, 2011, p. 260). Austin, for example, traveled from the warm, rainy North East to the arid, unfamiliar land between the Rio Colorado and the Rio Grande. Compared to the prosperous, comfortable North East, the Southwest was significantly wilder and more desolate. To foster effective communication with the local people, Austin utilizes a desert-adapted language to describe the region. Although she did not speak a desert language, in The Land of Journeys' Ending, she attempts to utilize a version of English that has more emphasis on the desert. Preferring a language that could adapt to suit the desert landscape, she sets an example for how to be attentive to local, natural conditions. According to Tom Lynch, "people migrate to new places, however, gaps open between language and place, for the more the new place differs from the place of origins, the more problematic will be the fit between word and world" (2008, p. 30). As a result, a more appropriate language necessarily originated from the arid country.

Austin also became incredibly intrigued with the various artistic endeavors of the Taos Native American clans, including their literature, local songs, and drama, which are all attentive to local, natural conditions. Since New Mexico was once occupied by Spanish conquistadores, the culture of the Taos was significantly influenced by Spanish culture, and their cultural prosperity continues to bear these traces. Austin writes,

It was the century whose beginning marked the height of the Spanish novel in 'Don Quixote'; in which Velasquez set the high mark of Spanish painting and Juan de Herrera achieved the Escorial. In that siglo de, oro, Lope de Vega wrote his thousand comedies, and Pedro Calderon his religious plays. Lope de Rueda regenerated the Spanish theater, introducing music between the acts, and sometimes into the acts, by which door grand opera came through. (p. 318)

Moreover, this unique artistic tradition is the combination of Spanish culture and the harsh environment of Southwest America, making it compatible with the local conditions. Literature flourished among the Taos between the sixteenth and seventeenth centuries. As part of their recreational activities, literature also enriched their spiritual life to some extent: "the people took the same interest in literature that they took in bull-fights" (p. 318). However, local people's passion for literature is evident, as almost every Tao develops the habit of reading novels in their spare time: "Since at that time the passion for novel-reading had, in the mother country, become almost a disease" (p. 320).

Music is a widely adopted and valuable possession of the local people that is seen as an integral part of their aboriginal culture, reflecting a love for life. The art of singing among these Native Americans also drew Austin's attention during her journey, as they seemed to have been born with this talent and the ability to create songs. Austin writes, "This is a singing land. Any aboriginal can make a song for you out of the material his life provides" (p. 321). In these aboriginal clans, folk songs can be heard almost 
anywhere nearby, and they also sing "ballads" (p. 321), "arias" (p. 321), and "hymns" (p. 323), which each have special meaning for different occasions. The heartfelt joy that is evoked by music gives people immense spiritual satisfaction in their life. Each person gains new insight, as they allow themselves to be immersed in music: "The young people dance to coplas composed for the occasion with all the air of improvisation, but doubtless long incubated in the poet's inner self, to be brought forth with premediated flourishes; young, simple couplets of compliment and lawful love” (p. 322). In New Mexico, the indigenous people sing songs during three important occasions: weddings, funerals, and velorios. For example, the forty-stanza song, "Advice to the newlywed," is likely to be sung at weddings. Meanwhile, the lyrics of the funeral chants and velorio chants are derived from "wellt-humbed books of almost indecipherable script" (p. 324). Austin explains that the tunes of the chants are irregularly varied: "Now it intones and hums in monkish monotones, or clears to pure Gregorian intervals, again it surprisingly turns off to recognizable phrases of Indian dance songs or wails like the alabados of the whipping processions of the Penitentes" (p. 324).

The local people are also particularly fond of plays, which enhance their spiritual richness. A native play has an irreplaceable position in the process of forming Taos artistic traditions. The manuscripts have been collected and passed down by memory. Through a series of local variations and adaptations, dramas have steadily become the primary genre. Although there are no professional directors or actors during the performance, the shepherd may be an important actor, for instance, as most locals merely appreciate the merriment that a drama performance evokes. It is no wonder, then, that the play, "Los Pastores," is one of the representative local dramas: "The properties are of the simplest, popular the artifices all those which with great solemnity have been heralded recently as new stage-craft; costumes symbolic rather than realistic, actors brought up through the audience" (p. 333). Other plays, like "Los Comanchos", the Kiss of Nino Dios, and "Matachine," are other annual plays that are popular among the locals.

All these cultural forms enhance the harmony within the community, as the locals try their best to preserve their cultural heritage. Austin was deeply attracted by the bioregional cultures that combined Native American and Spanish influences to successfully adapt to the local environment. Austin concentrates on describing the aboriginal cultures that live between the Rio Grande and Rio Colorado, reflecting how this cultural heritage was inherited from ancient peoples to be compatible with the local, natural conditions. To counter the homogenizing global culture, the locals adhere to indigenous culture, vernacular language, and regional customers, while remaining committed to the preservation of their local rites, ceremonies, language, and art that enrich their spiritual life. Austin praises the preservation of these local cultures in The Land of Journeys' Ending.

\section{Community and sustainability}

Austin advocates that the economic and political modes that are compatible with local, natural conditions should be preserved. These economic and political modes refer to two elements that maintain a community's sustainability. In other words, a self-efficient economy and politics that are adaptive to the local conditions are necessary for maintaining this stability. The economy of Southwest Native American clans relies on intertribal trade, which is undeveloped, causing native people to lead a simple material life. They are endowed with the capacity to trade for different daily-use items both within and between the clans. Undeniably, they are satisfied with their self-sufficient lifestyle. They obtain raw materials from places that are close to home, as they are fresher and healthier than transported food. As one of the central leaders of bioregionalism, Sale defines a bioregional economy: "A bioregional economy 
would seek to maintain rather than exploit the natural world, accommodate to the environment rather than resist it; it would attempt to create conditions for a climax, a balance, for what some economists have recently taken to calling a steady state (2000, p. 4)". In the Rio Grande, people used to gather at a rendezvous below Socorro to prepare for trade, which entailed "the management of trade caravans, trail masters, arrieros, and armed escorts " (Austin, 2007, p. 200). Other traders came from afar, including "trappers with mule-load of skins” (p. 200), cibolkros with sacks of buffalo jerky; hacienderos exchanging bales of homespun blankets for stallions to improve their stock; miners with bowl-shaped ingots made of smelted sliver and government-stamped lumps of soft New Mexico gold; and pueblo traders with turquoise and osha stones, who would bring beaver-skins and Navajo serapes (p. 200). Austin writes,

\begin{abstract}
From the first that we hear of them, Navajo blankets were especially esteemed, though they knew no color then but natural black and white wool, dark blue of a forgotten dye, and red which the women pick out of the crimson lining of Spanish officers' cloaks and rewove, the demand for which made such a scarcity of officers that the Government bethought itself and made bayeta, as the crimson cloth was called, a regular article of trade. The conducta went armed and cautiously along the Jornada del Muerto. At the water-holes in the Organos Mountains, which the atajo must visit or die, they were quite certain to find Apaches in ambush, to see that they died horribly. Some weeks later, when the conducta returned with silk cutlery, pineapples and carved leather, high Spanish combs, and brazilwood for dyes, it was all to be risked over again. There were also government supply-trains going up with gold coin to pay the official salaries and gold altar furnishings to content the missionaries. (p. 201)
\end{abstract}

The most famous center of intertribal trade is Chaco, where people from different bioregions, who have various needs, trade for a series of goods: salt, sea-shells, turquoise, and buffalo meat/hides. For example, the Zuni and Hopi clans often travel to Bonito and Chettro-Kettle in order to exchange turquoise "and salt for buffalo robes and hides" (p. 108) while the cliff towns of Mesa Verde bring eagle plums to "exchange for the many-colored feathers of the south" (p. 108).

In The Land of Journeys' Ending, the economy of the Native Americans was ultimately based on the principles of the natural world. However, they were far from deprived or impoverished. By adhering to this bioregional approach, they achieved sufficient economic health. At least to some degree, Austin promotes the maintenance of their local, self-sufficient trade, as opposed to the increasing dependence upon inter-regional and global trade. She holds that intertribal trade maintains the locals' self-sufficient economy without exploiting the natural world.

Austin created a detailed survey of the indigenous people's history, including their unique methods of organization, noting how no one attempts to impose upon them or establish a central source of power or sovereignty. Rather, they tend to live in separate, independent groups. Truly autonomous bioregions are likely to establish individual methods and political systems based on their clan's values, beliefs, standards, and customs that are oriented toward their bioregion.

During the Pit-house period, a cacique was the chief of individual Native American clans, and his main duty was to ensure the normal operations of daily life within the community. In the morning, the cacique would wake the village to participate in the morning tasks. The cacique of the Small-house people would keep watch from a boulder, but most of the time, rather than keeping an eye out for the enemy, the cacique would observe the game and corn. In addition, women had a relatively high position within the Small-house clans, a matriarchal society: "Not only was woman the food-divider, but the householder" (p. 73). The houses, which were built by the husbands, were considered the wives' ultimate possessions. 
Different clans had different ways of protecting their sovereignty and maintaining independence from the Spanish colonists. One hundred years ago, Spanish pioneers came to the Rio Grande and posed a serious threat to the Native Americans. The conflicts between them and the Pueblenos significantly influenced the stable, peaceful lives of the people. Finally, the Pueblenos united and fought for the clans' independence and sovereignty, driving out the colonists and moving their towns to more secure positions, like mesas. Then, "the roving tribes of Apache and Navajo" (p. 194) joined in the chaos, while the Zuni barricaded themselves on Thunder Mountain and San Ildefonso "retreated to the top of Black Mesa” (p. 194). The conflicts between the Pueblenos and colonists made people realize the importance of peace and stability in maintaining a sustainable community.

In general, some politicians envision a perfect political system that would suit any country, but this is unrealistic in today's diverse world, as it would ultimately produce a vapid society. Instead, we must dream of a system that allows people, like the variety of those portrayed in The Land of Journeys' Ending, to demonstrate their personalities. Austin writes,

But the uniqueness of the Pueblo contribution lies in its being, sole among the peoples of the cultural and economic interests. Here is the only organized group in which group-mindedness runs higher than the individual reach. This is the only society in the world in which culture exists as an expression of the whole, unaffected by schisms of class and caste, incapable of being rated in terms of power or property. (p. 263)

Austin believes that economic and political modes should be compatible with the local, natural conditions, and she advocates for a sustainable community. With the help of a local, self-sufficient economy and political modes that are adaptive to local conditions, Pueblo people are able to live comfortably. To maintain a sustainable, biotic community and meet their economic and political needs within their local area, the native people of the American Southwest try their best to break the conflict between wilderness and nature by taking measures to adhere to their local conditions when dealing with problems that arise. Despite their imperfect political systems and undeveloped economy, indigenous people live together equally and harmoniously.

\section{Conclusion}

By examining The Land of Journeys' Ending in light of bioregionalism, one may observe Austin's love for nature and her perspective regarding how to handle the relationship between humans and nature, which entails being dialectical as well as adaptive to local conditions. In Austin's opinion, instead of being in opposition, humans and nature should be intricately connected and even penetrate each other. She values the natural beings of the indigenous people's bioregion and appreciates the preservation of the people's bioregional culture. Austin proposes that humans should live within a certain area and learn about it in-depth to fully understand and experience it, including its nature, culture, economy, and politics. The material life of the residents is plain and simple, while their spiritual life is abundant. Materiality and spirituality are intimately connected in this sense.

Due to Austin's intense interest in bioregion-based cultures, she promotes their preservation in her work, especially those of the aborigines between the Rio Grande and Rio Colorado, who are also committed to this cause. In doing so, they maintain their cultural diversity and resist the dominant culture. Austin also upholds that the economic and political modes of a community should be compatible with local natural conditions, advocating for sustainability. Austin describes how natives utilize local materials as much as possible. Economically, intertribal trade plays an important role in improving indigenous people's economy. Meanwhile, the aim of bioregional politics is to maintain the sovereignty 
and stability of a bioregion, and although the political system is imperfect and their economic foundation undeveloped, local Native Americans in the Southwest live a simple, harmonious life, attuned to the rhythms of the land. They have created an ecologically informed and sustainable society, which is the ultimate goal of bioregionalism.

Austin argues that environmental problems should be solved from the perspective of bioregionalism. Although building this ideal relationship between nature and humans has a long way to go, she developed a bioregional consciousness by depicting Native American life in her work. These bioregional concepts in her work have significant implications when it comes to China's current efforts to promote ecological progress. Austin's stories involving a sense of place bring us closer to our neighbors and to resolving essential environmental challenges that are continually increasing in severity. Without learning how to listen to these stories and how to tell our stories more effectively, it is unlikely that we can evoke a caring attitude toward other places across the world. Austin's work is an important step toward sustainability because it enhances our ability to understand and appreciate the stories of different bioregions.

\section{References}

Austin, M. H. (2007). The land of journey's ending. Santa Fe: Sunstone Press.

Buell, L. (2005). The future of environmental criticism: environmental crisis and literary imagination. Oxford: Blackwell Publishing.

Champion, L. (2000). American women writers, 1900-1945: a bio-bibliographical critical sourcebook. London: Greenwood Press.

Garces, V. C. (2011). "Ecocriticism and translation." Odisea, 12,pp. 257-272.

Klimasmith, B. (2004). "Naturist as Tourist: Mary Austin's "Automobile Eye View" in The Land of Journey's Ending." Western American Literature, Volume 39, Number 1, pp. 54-78.

Lanigan, E. F. (1989). Mary Austin: song of a maverick. New Heaven: Yale University Press.

Lynch, T. (2008). Xerophilia: ecocritical explorations in Southwestern literature. Lubbock: Texas Tech University Press.

Norwood, V. (1993). Made from this earth: American women and nature. Chapel Hill and London: The University of Carolina Press.

Petterson, J. (2008). "Wrestling with "half gods": Biblical Discourse in Mary Austin's The Ford." Christianity and Literature, Vol. 67 (4), pp. 653-668.

Sale, K. (2000). Dwellers in the land: the bioregional vision. Athens: The University of Georgia Press.

Schaefer, H. (2004). Mary Austin's regionalism: reflections on gender, genre, and geography. Charlottesville and London: University of Virginia Press.

Stineman, E. F. L. (1987). "Mary Hunter Austin: an American woman of letters." Dissertation for the Degree of Doctor of Philosophy, Faculty of the Graduate School, Yale University.

Thayer Jr., R. B. (2003). Life place: bioregioal thought and practice. California: University of California Press.

Warren, J .P. (2014). The road to the spring: collected poems of Mary Austin. New York: Syracuse University Press. 